\title{
"Suggested Mathematical Model for Specialized Subcontractor Prequalification Scrutiny and Ultimately the Performance Prediction"
}

\author{
Mr. Mangesh M. Kapote ${ }^{1}$, Prof. Dr. S. S. Pimplikar ${ }^{2}$ \\ ${ }^{I}$ Student, M.E. (Construction \& Management), Maharashtra Institute of Technology, Pune, India. \\ ${ }^{2}$ Professor \& Head, Civil Engg. Dept, Maharashtra Institute of Technology, Pune, India.
}

\begin{abstract}
A large portion of the work done in construction projects is carried out by subcontractors. Thus it is very much essential to select a right subcontractor for project's success. Based on dependent, independent variables and their correlation, Weighted Point Score Method for prequalification scrutiny of subcontractor is suggested here with a Logistic Regression (LR) approach which ultimately helps in performance prediction of specialized subcontractor. The paper summarizes the Logistic Regression approach and its advantages, also the Weighted Point Score Method with quantification of different variables on 3 point scale which helps in selecting best suited subcontractor.
\end{abstract}

Keywords: Dependent Variable, Independent Variables, Logistic Regression (LR) Approach, Prequalification, Specialized Subcontractor, Weighted Point Score Method.

\section{Introduction}

Subcontracting is advantageous for the general contractors in many ways such as reduced capital investment for general contractors, speedy work, good quality work, reduced risk to general contractors, etc. Although the success of a project does not depend wholly on judicious subcontractor selection, choosing the right subcontractor is important because many defaults in the past have been due to subcontractors accepting jobs, they are incapable of undertaking and good subcontractors being given inappropriate contracts (Okoroh and Torrence 1999; Kumarswamy and Matthews 2000). Several sophisticated methods have already been proposed for the selection of main contractors and subcontractors such as multicriteria decision making, multiattribute analysis, multiple regression, cluster analysis, fuzzy set theory, multivariate discriminant analysis (Hatush and Skitmore 1997; Albino and Garvelli1998; Holt 1998; Mahdi et al. 2002). New findings pertaining to contractor prequalification, tender evaluation and modeling techniques for predicting contractor's performance are confirming that the subject area still justifies the investigation (eg., Abidali and Harris 1995; Tam and Harris 1996; Chinyio et al. 1998; Ng et al. 1999; Lam et al. 2000; Wong and Holt 2001).

This paper presents a weighted point score method for prequalification scrutiny of subcontractors with logistic regression (LR) approach. The dependent and independent variables are identified from literature survey and weightages are given to the independent variables by discussing with field professionals and literature survey analysis.

\section{Formulation of Mathematical Model:}

For convenience the independent variables are grouped in 8 catagories so as to generate the final form of the logistic regression as given below,

$\mathrm{Y}=$ Dependent Variable

$=$ The selection of an interested bidder to work as a subcontractor with a reputed contracting firm adopting a process based approach depends upon.

$\mathrm{X}=$ Independent Variable

$\mathrm{X} 1=$ Staff quality and Experience

$\mathrm{X} 2=$ Plant and Equipment resources

$\mathrm{X} 3$ = Subcontractor site management / execution capability

$\mathrm{X} 4=$ Health and Safety

$\mathrm{X} 5=$ Past performance records on similar projects

X6 = Subcontractor Reputation / Image

$\mathrm{X} 7=$ Subcontractor Proposal

$\mathrm{X} 8=$ Other Evaluation criteria

The Logistic Regression (LR) technique is used to determine how the probability of a subcontractor performance can be predicted (good or poor) from their previous completed projects.

In arithmetic terms, this relationship takes the form of, 


\section{$\mathrm{Y}=\mathrm{W} 0+\mathrm{W} 1 \mathrm{X} 1+\mathrm{W} 2 \mathrm{X} 2+\mathrm{W} 3 \mathrm{X} 3+\mathrm{W} 4 \mathrm{X} 4+\mathrm{W} 5 \mathrm{X} 5+\mathrm{W} 6 \mathrm{X} 6+\mathrm{W} 7 \mathrm{X} 7+\mathrm{W} 8 \mathrm{X8}$}

Where,

$$
\text { Eq......... (1) }
$$

\section{- $\quad \mathrm{Y}=$ Subcontractor's performance}

- $\quad \mathrm{W} 1, \mathrm{~W} 2, \ldots \ldots \mathrm{W} 8$ are the coefficients obtained by performing the logistic regression analysis.

- $\quad$ The values of X1, X2, X3, ......X8 will be obtained based on the weighted point scores averaged out for all the sub-variables as listed below

To start with, in this study, the weightages for the 8 variables are decided by the author based on the literature survey and discussion with the field experts.

However, these weightages need to be modified based on a larger database generated by interacting with more field professionals. In table 1; the various sub-variables concerned and their suggested weights are given.

Table: 1 Independent Variables and Weights Assighned

\begin{tabular}{|c|c|c|c|c|}
\hline & & Variables & Weight & Points \\
\hline $\mathbf{X 1}$ & & Staff quality and experience: & 25 & \\
\hline & $\mathrm{X} 11$ & Staff qualification & & \\
\hline & & X11A: General qualification & 2 & \\
\hline & & X11B: Qualification specific to the role played by the particular staff & 3 & \\
\hline & $\mathrm{X} 12$ & Staff experience: & & \\
\hline & & X12A: Experience within country & 2 & \\
\hline & & X12B: Experience outside the country & 2 & \\
\hline & & $\begin{array}{l}\text { X12C: Total years of experience of key techno-managerial personnel } \\
\text { (general). }\end{array}$ & 2 & \\
\hline & & $\begin{array}{l}\text { X12D: Years of experience of key techno-managerial personnel (specific o } \\
\text { nature of work). }\end{array}$ & 2 & \\
\hline & & $\begin{array}{l}\text { X12E: Total experience of experience of key techno-managerial personnel } \\
\text { (specific to the present subcontractor's organization) }\end{array}$ & 2 & \\
\hline & & & & \\
\hline & $\mathrm{X} 13$ & Staff training & & \\
\hline & & X13A: General training & 2 & \\
\hline & & X13B: Training particular to role played & 2 & \\
\hline & $\mathrm{X} 14$ & Performance of work site incharge & & \\
\hline & & X14A: As demonstrated from the results measured on site & 2 & \\
\hline & & X14B: As per the score / grade obtained in HR appraisal & 1 & \\
\hline & $\mathrm{X} 15$ & Demonstrated Competencies & 3 & \\
\hline $\mathbf{X 2}$ & & Plant and Equipment Resources (As applicable) & $\mathbf{1 0}$ & \\
\hline & $\mathrm{X} 21$ & Nos. of plants and equipments available, their capacity & 5 & \\
\hline & $\mathrm{X} 22$ & Condition and procedure of equipment handling, management & 3 & \\
\hline & $\mathrm{X} 23$ & Suitability of equipment to particular nature of work & 2 & \\
\hline $\mathbf{X 3}$ & & Subcontractor site management / execution capacity & 25 & \\
\hline & $\mathrm{X} 31$ & Type of control and monitoring procedure & 8 & \\
\hline & $\mathrm{X} 32$ & Cost control and construction progress reporting system & 7 & \\
\hline & X33 & Risk Management & 5 & \\
\hline & X34 & IT Knowledge Eg. Electronic Document Management System & 5 & \\
\hline $\mathbf{X 4}$ & & Health and Safety $(\mathrm{H} \& S)$ & 15 & \\
\hline & $\mathrm{X} 41$ & Proposed H \& S program & 4 & \\
\hline & $\mathrm{X} 42$ & $\mathrm{H} \& \mathrm{~S}$ records on previous projects & 4 & \\
\hline & & & & \\
\hline & $\mathrm{X} 43$ & Demonstration of commitment to the actual implementation & 4 & \\
\hline & $\mathrm{X} 44$ & Insurance policies and Type of coverage & 3 & \\
\hline & & & & \\
\hline $\mathbf{X 5}$ & & Past performance records on similar projects & 15 & \\
\hline & $\mathrm{X} 51$ & Timely performance & 4 & \\
\hline & & & & \\
\hline
\end{tabular}


“Suggested Mathematical Model for Specialized Subcontractor Prequalification Scrutiny .......

\begin{tabular}{|c|c|c|c|c|}
\hline & $\mathrm{X} 52$ & Cost control demonstrated or otherwise & 4 & \\
\hline & $\mathrm{X} 53$ & Ouality aspect adhered to and to what extent & 4 & \\
\hline & & & & \\
\hline & $\mathrm{X} 54$ & Attitude wrt. raising claims and disputes, litigation & 3 & \\
\hline \multirow[t]{9}{*}{$\mathbf{X 6}$} & & Subcontractor Reputation / Image & 35 & \\
\hline & X61 & Subcontractor Reputation & 4 & \\
\hline & X62 & Origin of the company, legal status, growth and development & 3 & \\
\hline & X63 & Financial status linked with nos. of years in business & & \\
\hline & & X63A: Net asset worth & 5 & \\
\hline & & X63B: Annual avg. turnover in previous 3-5 yrs. & 5 & \\
\hline & & X63C: Avg. profitability in previous 3-5 yrs. & 5 & \\
\hline & & X63D: Debt : Equity Ratio & 3 & \\
\hline & & X63E: Avg. liquidity in previous 3-5 yrs. based on Acid Test Ratio & 10 & \\
\hline \multirow[t]{8}{*}{$\mathbf{X} 7$} & & Subcontractor Proposal & 15 & \\
\hline & $\mathrm{X} 71$ & Adherence to construction schedules and procedures & 3 & \\
\hline & & & & \\
\hline & $\mathrm{X} 72$ & Adherence to construction method control statement & 3 & \\
\hline & $\mathrm{X} 73$ & Site organization, work rules / procedure and policies & 3 & \\
\hline & $\mathrm{X} 74$ & Proposed site management and productivity improvement procedures & 3 & \\
\hline & & & & \\
\hline & $\mathrm{X} 75$ & Proposed tender price and extent of negotiations & 3 & \\
\hline \multirow[t]{9}{*}{$\mathbf{X 8}$} & & Other Evaluation Criteria & 20 & \\
\hline & $\mathrm{X} 81$ & Subcontractor familiarity with weather conditions & 3 & \\
\hline & $\mathrm{X} 82$ & Subcontractor familiarity with local labours & 2 & \\
\hline & & & & \\
\hline & $\mathrm{X} 83$ & Subcontractor familiarity with local suppliers & 4 & \\
\hline & $\mathrm{X} 84$ & Subcontractor familiarity with geography of the area & 3 & \\
\hline & & & & \\
\hline & $\mathrm{X} 85$ & Subcontractor familiarity with local authority & 4 & \\
\hline & $\mathrm{X} 86$ & $\begin{array}{l}\text { Subcontractor relationship with other agencies related to the work and with } \\
\text { the personnel of main contractor }\end{array}$ & 4 & \\
\hline & & & & \\
\hline
\end{tabular}

\section{Logistic Regression Technique:}

Logistic regression is a mathematical modeling approach which describes the occurrence or nonoccurrence of an event (Kleinbaum 1994; Tung 1985). This dichotomous probability is measured by 0 or 1 . In this study, 0 is for indicating the occurrence of "good" subcontractor and 1, otherwise. A LR model "predicts" the odds of an event occurring (i.e., ratio of the probability that good contractor performance will occur to the probability that it will not). Suppose a linear sum expression for deriving a functional relationship between $\mathrm{Y}$ and $\mathrm{Xn}$ i.e., Eq. (1).

In order to construct a logistic model that can be used to describe the dichotomous (binary ) dependent variable as a function of a number of independent variables, the probability function can be written as (Norusis 1994; Sharma 1996).

$$
\ln \left(\frac{\mathrm{P}}{1-\mathrm{P}}\right)=W 0+W 1 X 1
$$

Or

$$
P=\frac{1}{1+e^{-(W 0+W 1 X 1)}}
$$

Assume there is only one independent variable,

Where

$\mathrm{P}=$ probability of occurrence; 
$\mathrm{W} 0=$ constant;

$\mathrm{W} 1=$ coefficient estimated from the data; and

$\mathrm{X} 1=$ independent variable.

When the independent variable is more than one, the LR model can be written as,

$$
P=\frac{1}{1+e^{-(Y)}}
$$

Where, $\mathrm{Y}=$ subcontractor's performance as calculated from equation (1)

probability (of a good subcontractor) is given by 1 over 1 plus e to the minus the quantity of Eq. (1).

From Eq. (3) logistic coefficients can be interpreted as change in the log odds associated with a one-unit change in independent variables. To shorten the notation, when considering the probabilities of contractor performance, the logistic model will describe a probability of getting a good (or poor ) contractor with the cut of value of 0.5 (Fig. 1). The predicted contractor performance will fall between the good or poor group regardless of the types and values of independent variables.

The Logistic Regression Analysis can be performed using SPSS 10.0, which also facilitates provision of a stepwise procedure for the selection of input ( independent ) variables and goodness-of-fit statistics for the developed model. A detailed description of the basic concept and techniques of the program can be found in SPSS - Advanced statistics 6.1 (Norusis 1994).

To summarize, LR analysis in this study enables:

- the prediction of subcontractor performance, which lies in the range between good and poor groups;

- the demonstration of the (combined ) effect of input variables on dichotomous dependent variables; and

- ultimately to produce a subcontractor performance prediction model.

Table 2 : Benchmarking suggested for 3- point score of individual variable

\begin{tabular}{|c|c|c|c|}
\hline & 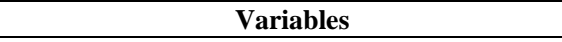 & Quantification & Points \\
\hline $\mathbf{X 1}$ & Staff Quality and Experience & & \\
\hline \multirow[t]{10}{*}{$\mathrm{X} 11$} & Staff Qualification & & \\
\hline & X11A : General Qualification & a) Degree in Civil Engineering(BE) & 3 \\
\hline & & b) Diploma in Civil Engineering (DCE) & 2 \\
\hline & & c) ITI/Equivalent in Civil works & 1 \\
\hline & & d) No Diploma/Degree/ITI & 0 \\
\hline & & & \\
\hline & X11B : Specific Qualification & $\begin{array}{l}\text { a) Post Graduate (ME/Mitch) in Civil } \\
\text { Engineering(Specialization) }\end{array}$ & 3 \\
\hline & & b) Degree in Civil Engineering(BE) & 2 \\
\hline & & $\begin{array}{l}\text { c) Diploma/PGD with specific area in Civil } \\
\text { Engineering }\end{array}$ & 1 \\
\hline & & d) No specific qualification & 0 \\
\hline \multirow[t]{21}{*}{$\mathrm{X} 12$} & Staff Experience & & \\
\hline & $\mathrm{X} 12 \mathrm{~A}$ : Experience within country & a) $>10 \mathrm{yrs}$ & 3 \\
\hline & & b) $7-10 \mathrm{yrs}$ & 2 \\
\hline & & c) $5-7$ yrs & 1 \\
\hline & & d) $<5$ yrs & 0 \\
\hline & X12B : Experience outside the country & a) $>8$ yrs & 3 \\
\hline & & b) $6-8 \mathrm{yrs}$ & 2 \\
\hline & & c) 4-6 yrs & 1 \\
\hline & & d) $<4$ yrs & 0 \\
\hline & X12C : Total General experience & a) $>10 \mathrm{yrs}$ & 3 \\
\hline & & b) $7-10$ yrs & 2 \\
\hline & & c) $5-7$ yrs & 1 \\
\hline & & d) $<5 \mathrm{yrs}$ & 0 \\
\hline & $\mathrm{X} 12 \mathrm{D}$ : Experience specific to Nature of work & a) $>8$ yrs & 3 \\
\hline & & b) $6-8 \mathrm{yrs}$ & 2 \\
\hline & & c) 4-6 yrs & 1 \\
\hline & & d) $<4 \mathrm{yrs}$ & 0 \\
\hline & & & \\
\hline & $\begin{array}{l}\text { X12E : Total experience specific to present Sub- } \\
\text { contractor's organization }\end{array}$ & a) $>6$ yrs & 3 \\
\hline & & b) 5-6 yrs & 2 \\
\hline & WWW.ios & 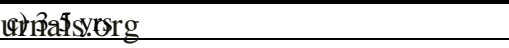 & 46 \\
\hline
\end{tabular}


"Suggested Mathematical Model for Specialized Subcontractor Prequalification Scrutiny .......

\begin{tabular}{|c|c|c|c|}
\hline & & d) $<3 \mathrm{yrs}$ & 0 \\
\hline \multirow[t]{7}{*}{$\mathrm{X} 13$} & Staff Training & & \\
\hline & X13A : General Training & a) Yes & 3 \\
\hline & & b) No & 0 \\
\hline & X13B : Specific Training & a) Excellent & 3 \\
\hline & & b) Good & 2 \\
\hline & & c) Average & 1 \\
\hline & & d) Poor & 0 \\
\hline \multirow[t]{9}{*}{$\mathrm{X} 14$} & Performance of Work Site In charge & & \\
\hline & $\begin{array}{l}\text { X14A : As demonstrated from the results measured } \\
\text { on site }\end{array}$ & a) Excellent & 3 \\
\hline & & b) Good & 2 \\
\hline & & c) Average & 1 \\
\hline & & d) Poor & 0 \\
\hline & $\begin{array}{l}\text { X14B : As per Grade/Score obtained in HR } \\
\text { Appraisal }\end{array}$ & a) Excellent & 3 \\
\hline & & b) Good & 2 \\
\hline & & c) Average & 1 \\
\hline & & d) Poor & 0 \\
\hline \multirow[t]{4}{*}{$\mathrm{X} 15$} & Demonstrated Competencies & a) Excellent & 3 \\
\hline & & b) Good & 2 \\
\hline & & c) Average & 1 \\
\hline & & d) Poor & 0 \\
\hline $\mathbf{X 2}$ & Plant \& Equipment Resources & & \\
\hline \multirow[t]{4}{*}{$\mathrm{X} 21$} & $\begin{array}{l}\text { Number of plants and equipments available and } \\
\text { their capacity }\end{array}$ & $\begin{array}{l}\text { a) Number matching the full requirement of } \\
\text { site/work and capacity utilization maximum }\end{array}$ & 3 \\
\hline & & b) Number matching but equipment not fully utilized & 2 \\
\hline & & c) Overall avg. performance of existing equip. & 1 \\
\hline & & d) Not matching the requirement of site & 0 \\
\hline \multirow[t]{4}{*}{$\mathrm{X} 22$} & $\begin{array}{l}\text { Condition and procedure of Equipment handling, } \\
\text { Management }\end{array}$ & $\begin{array}{l}\text { a) Document procedure exists, also properly } \\
\text { implemented and equipment is in good working } \\
\text { condition }\end{array}$ & 3 \\
\hline & & $\begin{array}{l}\text { b) Document procedure exists and properly } \\
\text { implemented but equipment is not so good }\end{array}$ & 2 \\
\hline & & $\begin{array}{l}\text { c) Document procedure exists but not properly } \\
\text { implemented and also equipment condition is not } \\
\text { good }\end{array}$ & 1 \\
\hline & & $\begin{array}{l}\text { d) No documented procedure and its implementation } \\
\text { is also poor and also equipment condition is not } \\
\text { good }\end{array}$ & 0 \\
\hline \multirow[t]{2}{*}{$\mathrm{X} 23$} & Suitability of Equipment to particular work & a) Suitable & 3 \\
\hline & & b) Not suitable & 0 \\
\hline $\mathbf{X 3}$ & $\begin{array}{l}\text { Subcontractor's site management / Execution } \\
\text { capability }\end{array}$ & & \\
\hline \multirow[t]{4}{*}{$\mathrm{X} 31$} & $\begin{array}{l}\text { Type of Management control for effective } \\
\text { monitoring of the performance of Construction } \\
\text { equipments }\end{array}$ & a)Full control at execution level & 3 \\
\hline & & b) Control shared between office and site & 2 \\
\hline & & $\begin{array}{l}\text { c) Control mechanism exists but weak } \\
\text { implementation }\end{array}$ & 1 \\
\hline & & d) Non-existence of Control mechanism & 0 \\
\hline \multirow[t]{3}{*}{$\mathrm{X} 32$} & $\begin{array}{l}\text { Cost control and Construction progress reporting } \\
\text { system }\end{array}$ & $\begin{array}{l}\text { a) Use of scientific Cost control techniques and } \\
\text { properly documented progress reporting system }\end{array}$ & 3 \\
\hline & & $\begin{array}{l}\text { b) Use of scientific Cost control techniques but not } \\
\text { properly documented progress reporting system }\end{array}$ & 2 \\
\hline & & $\begin{array}{l}\text { c) No use of scientific Cost control techniques but } \\
\text { properly documented progress reporting system }\end{array}$ & 1 \\
\hline
\end{tabular}


“Suggested Mathematical Model for Specialized Subcontractor Prequalification Scrutiny ......

\begin{tabular}{|c|c|c|c|}
\hline & & $\begin{array}{l}\text { c) Non existence of scientific Cost control and } \\
\text { Construction progress reporting system }\end{array}$ & 0 \\
\hline \multirow[t]{4}{*}{ X33 } & Risk Management & $\begin{array}{l}\text { a) Use of scientific quantitive models for risk } \\
\text { assessment and use of softwares }\end{array}$ & 3 \\
\hline & & $\begin{array}{l}\text { b) Use of software for risk assessment but no } \\
\text { scientific quantitive models }\end{array}$ & 2 \\
\hline & & $\begin{array}{l}\text { c) Use of scientific quantitive models for risk } \\
\text { assessment but no use of softwares }\end{array}$ & 1 \\
\hline & & $\begin{array}{l}\text { d) No use of quantitive model and software for risk } \\
\text { assessment }\end{array}$ & 0 \\
\hline \multirow[t]{4}{*}{$\mathrm{X} 34$} & IT Knowledge & $\begin{array}{l}\text { a) Use of softwares like ERP/SAP for project } \\
\text { monitoring and control. Also, MSP/Primavera for } \\
\text { project schedule control }\end{array}$ & 3 \\
\hline & & $\begin{array}{l}\text { b) Use of softwares like ERP/SAP for project } \\
\text { monitoring and control but no use of } \\
\text { MSP/Primavera }\end{array}$ & 2 \\
\hline & & $\begin{array}{l}\text { c) Use of MSP/Primavera for project schedule } \\
\text { control but no use of ERP/SAP }\end{array}$ & 1 \\
\hline & & d) Poor IT knowledge & 0 \\
\hline $\mathbf{X 4}$ & Health and Safety & & \\
\hline \multirow[t]{4}{*}{$\mathrm{X} 41$} & Proposed H \& S program & $\begin{array}{l}\text { a) Certification of both OHSAS } 18001 \text { and } \\
\text { EMS/ISO } 14001 \text { from accredited body and its proper } \\
\text { implementation }\end{array}$ & 3 \\
\hline & & $\begin{array}{l}\text { b) Certification of both OHSAS } 18001 \text { or EMS/ISO } \\
14001 \text { and its improper implementation }\end{array}$ & 2 \\
\hline & & $\begin{array}{l}\text { c) Certification of } \mathrm{H} \& \mathrm{~S} \text { standards but weak } \\
\text { implementation }\end{array}$ & 1 \\
\hline & & d) Non-existence of $\mathrm{H} \& \mathrm{~S}$ program & 0 \\
\hline \multirow[t]{4}{*}{$\mathrm{X} 42$} & $\begin{array}{l}\mathrm{H} \& \mathrm{~S} \text { records on previous projects(credential } \\
\text { certificates if any) }\end{array}$ & a) Excellent & 3 \\
\hline & & b) Good & 2 \\
\hline & & c) Average & 1 \\
\hline & & d) Poor & 0 \\
\hline \multirow[t]{4}{*}{$\mathrm{X} 43$} & $\begin{array}{l}\text { Demonstration of Commitment to the actual } \\
\text { implementation(feedback from previous projects } \\
\text { completed) }\end{array}$ & a) Excellent & 3 \\
\hline & & b) Good & 2 \\
\hline & & c) Average & 1 \\
\hline & & d) Poor & 0 \\
\hline \multirow[t]{4}{*}{$\mathrm{X} 44$} & Insurance policies and type of coverage & a) CAR policy for all staff as well as equipments & 3 \\
\hline & & b) CAR policy for all equipments but not for staff & 2 \\
\hline & & c) CAR policy for all staff but not for equipments & 1 \\
\hline & & d) Non-existence of insurance policies & 0 \\
\hline $\mathbf{X 5}$ & Past performance records on similar projects & & \\
\hline \multirow[t]{4}{*}{$\mathrm{X} 51$} & Timely performance & $\begin{array}{l}\text { a) Averagely on time completion of project with } \\
\text { proper good quality }\end{array}$ & 3 \\
\hline & & $\begin{array}{l}\text { b) Averagely before time completion of project with } \\
\text { satisfactory quality }\end{array}$ & 2 \\
\hline & & c)Averagely small delay for completion of project & 1 \\
\hline & & d)Averagely large delay for completion of project & 0 \\
\hline \multirow[t]{4}{*}{$\mathrm{X} 52$} & Cost control demonstrated & a)Full Cost control at execution level & 3 \\
\hline & & b) Cost Control shared between office and site & 2 \\
\hline & & $\begin{array}{l}\text { c) Cost Control mechanism exists but weak } \\
\text { implementation }\end{array}$ & 1 \\
\hline & & d) Non-existence of Cost Control mechanism & 0 \\
\hline \multirow[t]{2}{*}{ X53 } & Adherence to Quality aspects & $\begin{array}{l}\text { a) ISO } 9001 \text { and/or similar quality certification with } \\
\text { proper implementation and management }\end{array}$ & 3 \\
\hline & & $\begin{array}{l}\text { b) ISO } 9001 \text { and/or similar quality certification but } \\
\text { averagely satisfactory implementation and } \\
\text { management }\end{array}$ & 2 \\
\hline
\end{tabular}


“Suggested Mathematical Model for Specialized Subcontractor Prequalification Scrutiny ......

\begin{tabular}{|c|c|c|c|}
\hline & & $\begin{array}{l}\text { c) ISO } 9001 \text { and/or similar quality certification but } \\
\text { weak implementation }\end{array}$ & 1 \\
\hline & & d) No adherence to Quality policy & 0 \\
\hline \multirow[t]{4}{*}{$\mathrm{X} 54$} & Attitude w.r.t raising claims & $\begin{array}{l}\text { a) No claims or disputes with contracting party on } \\
\text { previous projects(feedback) }\end{array}$ & 3 \\
\hline & & $\begin{array}{l}\text { b)Minimum number of disputes with proper } \\
\text { evidence(minimum as per contractor's view) }\end{array}$ & 2 \\
\hline & & c) Claims raised, but disputes settled & 1 \\
\hline & & $\begin{array}{l}\text { d) Bad attitude of raising claimsand not settling } \\
\text { them ( feedback from previous projects) }\end{array}$ & 0 \\
\hline X6 & Sub Contractor's Reputation / Image & & \\
\hline \multirow[t]{4}{*}{ X61 } & Sub Contractor' reputation & $\begin{array}{l}\text { a) Successfully completed projects within time and } \\
\text { budget. also good relations with local } \\
\text { labours,suppliers and authority }\end{array}$ & 3 \\
\hline & & $\begin{array}{l}\text { b) Successfully completed projects but no good } \\
\text { relations with local labours,suppliers and authority }\end{array}$ & 2 \\
\hline & & $\begin{array}{l}\text { c) Cost and time over runs but good relation with } \\
\text { local labours,suppliers and authority }\end{array}$ & 1 \\
\hline & & d) Bad reputation & 0 \\
\hline \multirow[t]{4}{*}{$\mathrm{X} 62$} & Origin, growth and development & $\begin{array}{l}\text { a) Origin }>20 \text { yrs with excellent record of growth \& } \\
\text { development }\end{array}$ & 3 \\
\hline & & $\begin{array}{l}\text { b)Origin 10-20 yrs with good record of growth \& } \\
\text { development }\end{array}$ & 2 \\
\hline & & $\begin{array}{l}\text { c)Origin 5-10 yrs with averagely good record of } \\
\text { growth \& development }\end{array}$ & 1 \\
\hline & & $\begin{array}{l}\text { d) Origin }<5 \text { yrs with poor record of growth \& } \\
\text { development }\end{array}$ & 0 \\
\hline \multirow[t]{21}{*}{$\mathbf{X 6 3}$} & $\begin{array}{l}\text { Financial status linked with nos. of yrs in } \\
\text { business }\end{array}$ & & \\
\hline & X63A: Net Asset Worth & a) $>40 \%$ of project cost & 3 \\
\hline & & b) $30-40 \%$ of project cost & 2 \\
\hline & & c) $15-30 \%$ of project cost & 1 \\
\hline & & d) $<15 \%$ of project cost & 0 \\
\hline & X63B: Annual avg. turnover in previous 3-5 yrs. & a) $>1.5$ times the project cost & 3 \\
\hline & & b) $1.25-1.5$ times the project cost & 2 \\
\hline & & c)1-1.25 times the project cost & 1 \\
\hline & & d) $<$ project cost & 0 \\
\hline & X63C: Avg. profitability in previous 3-5 yrs. & a) $>10 \%$ & 3 \\
\hline & & b) $5-10 \%$ & 2 \\
\hline & & c) $>2 \%$ but $<5 \%$ & 1 \\
\hline & & d)Less than $2 \%$ & 0 \\
\hline & X63D: Debt : Equity ratio & a) $1: 1$ & 3 \\
\hline & & b) $2: 1$ & 2 \\
\hline & & c) $3: 1$ & 1 \\
\hline & & d) $4: 1$ & 0 \\
\hline & X63E: Avg. liquidity in previous 3-5 yrs. & a) $>30 \%$ of project cost & 3 \\
\hline & & b) $20-30 \%$ of project cost & 2 \\
\hline & & c) $10-20 \%$ of project cost & 1 \\
\hline & & d) $<10 \%$ of project cost & 0 \\
\hline $\mathbf{X 7}$ & Subcontractor Proposal & & \\
\hline \multirow[t]{4}{*}{$\mathrm{X} 71$} & Adherence to construction schedules \& procedure & $\begin{array}{l}\text { a) Use of softwares \& techniques for schedule } \\
\text { control and its proper implementation (MSP/Prima } \\
\text { Vera) }\end{array}$ & 3 \\
\hline & & $\begin{array}{l}\text { b) Use of softwares but averagely good handling and } \\
\text { management }\end{array}$ & 2 \\
\hline & & c) Use of softwares but weak management & 1 \\
\hline & & $\begin{array}{l}\text { d) No use of construction schedule techniques and } \\
\text { softwares }\end{array}$ & 0 \\
\hline
\end{tabular}


“Suggested Mathematical Model for Specialized Subcontractor Prequalification Scrutiny ......

\begin{tabular}{|c|c|c|c|}
\hline $\mathrm{X} 72$ & $\begin{array}{l}\text { Adherence to construction method control } \\
\text { statements }\end{array}$ & $\begin{array}{l}\text { a) Work rules \& policies with proper procedure and } \\
\text { its implementation on site }\end{array}$ & 3 \\
\hline & & $\begin{array}{l}\text { b)Work rules \& policies exists but averagely good } \\
\text { implementation on site }\end{array}$ & 2 \\
\hline & & $\begin{array}{l}\text { c) Work rules \& policies exists but weak } \\
\text { implementation on site }\end{array}$ & 1 \\
\hline & & d) Poor adherence to method control statements & 0 \\
\hline \multirow[t]{4}{*}{$\mathrm{X} 73$} & $\begin{array}{l}\text { Site organization, work rules/procedures \& } \\
\text { policies }\end{array}$ & $\begin{array}{l}\text { a) Site organization having proper coordination with } \\
\text { work rules \& policies also its management }\end{array}$ & 3 \\
\hline & & $\begin{array}{l}\text { b) Site organization with work rules \& policies but } \\
\text { Averagely good management }\end{array}$ & 2 \\
\hline & & $\begin{array}{l}\text { c) Site organization with work rules \& policies but } \\
\text { poor management }\end{array}$ & \\
\hline & & $\begin{array}{l}\text { d) Non existence of work rules and policies and poor } \\
\text { management }\end{array}$ & 0 \\
\hline \multirow[t]{4}{*}{ X74 } & $\begin{array}{l}\text { Proposed site management and productivity } \\
\text { improvement procedures }\end{array}$ & $\begin{array}{l}\text { a) Different departments of a proposed project with } \\
\text { proper coordination in between and actual } \\
\text { implementation of productivity improvement } \\
\text { techniques }\end{array}$ & 3 \\
\hline & & $\begin{array}{l}\text { b) Different departments of a proposed project with } \\
\text { averagely good coordination in between and actual } \\
\text { implementation of productivity improvement } \\
\text { techniques }\end{array}$ & 2 \\
\hline & & $\begin{array}{l}\text { c)Different departments of a proposed project with } \\
\text { poor coordination in between and actual } \\
\text { implementation of productivity improvement } \\
\text { techniques }\end{array}$ & 1 \\
\hline & & $\begin{array}{l}\text { d)Poor coordination and no implementation of } \\
\text { productivity improvement techniques }\end{array}$ & 0 \\
\hline \multirow[t]{4}{*}{ X75 } & Proposed tender price and extent of negotiation & a) Tender price as per contractor's requirement & 3 \\
\hline & & $\begin{array}{l}\text { b) Tender price more or less but negotiable with } \\
\text { contractor }\end{array}$ & 2 \\
\hline & & $\begin{array}{l}\text { c)Too less tender price (TP }<30 \% \text { or more of actual } \\
\text { TP) }\end{array}$ & 1 \\
\hline & & $\begin{array}{l}\text { d)Tender price not anywhere matching the } \\
\text { contractor's requirement }\end{array}$ & 0 \\
\hline X8 & Other Evaluation Criteria & & \\
\hline \multirow[t]{2}{*}{ X81 } & Subcontractor's familiarity with weather condition & a) Yes & 3 \\
\hline & & b) No & 0 \\
\hline \multirow[t]{4}{*}{ X82 } & $\begin{array}{l}\text { Subcontractor's familiarity with local labours of } \\
\text { different areas of civil engg. }\end{array}$ & a) Excellent & 3 \\
\hline & & b) Good & 2 \\
\hline & & c) Average & 1 \\
\hline & & d) Poor & 0 \\
\hline \multirow[t]{4}{*}{ X83 } & $\begin{array}{l}\text { Subcontractor's familiarity with local suppliers of } \\
\text { different areas of civil engg. }\end{array}$ & a) Excellent & 3 \\
\hline & & b) Good & 2 \\
\hline & & c) Average & 1 \\
\hline & & d) Poor & 0 \\
\hline \multirow[t]{2}{*}{ X84 } & $\begin{array}{l}\text { Subcontractor's familiarity with geography of the } \\
\text { area. }\end{array}$ & a) Yes & 3 \\
\hline & & b) No & 0 \\
\hline \multirow[t]{4}{*}{ X85 } & $\begin{array}{l}\text { Subcontractor's familiarity with local authority } \\
\text { regarding permission/approval/NOC of different } \\
\text { activities in civil engg. }\end{array}$ & a) Excellent & 3 \\
\hline & & b) Good & 2 \\
\hline & & c) Average & 1 \\
\hline & & d) Poor & 0 \\
\hline X86 & Subcontractor's relationship with other agencies & a) Excellent & 3 \\
\hline
\end{tabular}




\begin{tabular}{|l|l|l|l|} 
& & \\
\hline & and contractor's personnel & b) Good & 2 \\
\hline & & c) Average & 1 \\
\hline & & d) Poor & 0 \\
\hline
\end{tabular}

The Benchmarking suggested for 3 point score of individual variables is detailed out in Table 2 .

\section{Dicussion}

While assigning 1 or 0 to the main variable, for using in the logistic regression, the scores will be worked out as a product of the weights of each individual sub-variable and the points obtained. For each variable if the score obtained is greater than $70 \%$ then only the variable will be assigned a ' 0 ' i.e. 'Good' attribute. Otherwise it will be assigned ' 1 '. This approach enables the subjective analysis at the micro-level, but with an objective quantification and yet clearly discriminates between the good and the poor subcontractor. Needless to mention, a poor subcontractor certainly must get rejected. The $70 \%$ criteria thus provides a stringent methodology for deciding good or bad; based on comprehensive subcontractor evaluation.

\section{Conclusion}

The various recent advancements in the selection of subcontractors and evaluation methods highlights the need for diverse subcontractor assessment options due to increased project complexity and contractor's or client's demands. However, deciding which method to apply from a wide range of alternatives is crucial and difficult when the methods for evaluating a subcontractor performance are too sophisticated to understand and utilize by construction professionals. Therefore, when deciding the most 'suitable' selection method, the decision maker's preferences and weightages given to each evaluation criteria is very much important.

Based on the findings from the literature survey, the Logistic Regresion technique has the advantage and offers the potential for subcontractor performance prediction.

This paper also gives the relative importance of criteria used by contractors to select subcontractors with appropriate weightages and quantification based on 3 point scale by interaction with field professionals and literature survey.

\section{References}

[1]. Albino, V., and Garavelli, A.C. (1998). “A neural network application in sub- contractor rating in construction firms”. Int. J. Proj. Manage., 16(1), 9-14.

[2]. Andreas Hartmann; Florence Yean Yng Ling; and Jane S. H. Tan (2009). "Relative Importance of Subcontractor Selection Criteria: Evidence From Singapore". J. Constr. Eng. Manage. 2009.135:826-832.

[3]. Chee Hong Wong (2004). "Contractor Performance Prediction Model For The United Kingdom Construction Contractor: Study of Logistic Regression Approach”. J. Constr. Eng. Manage. 2004.130:691-698.

[4]. Holt, G. D. (1995). "A Methodology For Predicting The Performance of Construction Contractors". PhD thesis, Univ. of Wolverhampton, UK.

[5]. Hunt, H. W., Logan, Corbetta, R. H., Bayard, Bogen, S.A. (1966). "Contract Award Practices”. J. Constr. Div., Am. Soc. Civ. Eng., 92(1), 1-16.

[6]. Kumarswamy and Matthews, J. D. (2000). “Improved subcontractor selection employing partnering principles”. J. Manage. Eng. , 16(3), 47-57.

[7]. Russell, J. S. ,Hancher, D. E. ,and Skibniewski, M. J.,(1992). “Contractor prequalification data for construction owners”. Constr. Manage. Econom., 10, 117-135. 